\title{
DESIGN AND VALIDATION OF THE SELF-CARE BEHAVIORS SCALE
}

\author{
Nissa Yaing Torres Soto1, Víctor Corral Verdugo², Nadia Saraí Corral \\ Frías $^{2}$ and María de Lourdes Rojas Armadillo ${ }^{1}$ \\ ${ }^{1}$ University of Quintana Roo; ${ }^{2}$ University of Sonora (Mexico)
}

\begin{abstract}
Self-care constitutes a series of actions and behavior that contributes to individuals life, health and well-being maintenance and represents a relevant construct in diverse psychological areas. The purpose of this study is to develop the Self-Care Behaviors Scales and evaluate its psychometric properties. The sample included 235 individuals $(M=29.11$ years, $S D=10.53)$ from northern Mexico. To analyze the structure, a factorial exploratory analysis, revealed the existence of three factors (physical self-care, psychological self-care, spiritual self-care) that would explain $54 \%$ of total covariance. A three-factor analysis of covariance allowed adequate goodness-of-fit indices and the calculation of the mean variance extracted. The scale obtained evidence of convergent and discriminant validity. The internal consistency indices of the total score and the subscales were high (between .93 to .96). The significant correlation between these factors with personal variables provided evidence of the concurrent validity of the scale.

KEY WORDS: self-care behavioral, physical self-care, psychological self-care, spiritual self-care.
\end{abstract}

\section{Resumen}

El autocuidado constituye un conjunto de acciones y comportamientos que contribuyen a mantener la vida, la salud y el bienestar de los individuos y representa un constructo de relevancia en diversas áreas de la psicología. El propósito del presente estudio fue desarrollar la "Escala de conductas de autocuidado" y evaluar sus propiedades psicométricas. La muestra incluyó a 235 personas $(M=29.11$ años; $D T=10.53$ ) de México, siendo el $61.3 \%$ mujeres. Para analizar la estructura de la escala se realizó un análisis factorial exploratorio, que reveló la existencia de tres factores (físico, psicológico y espiritual) que explicaron el $54.18 \%$ de la varianza total. Un análisis de covarianzas de tres factores produjo índices de bondad de ajuste adecuados y el cálculo de varianza media extraída. La escala obtuvo evidencias de validez convergente y discriminante. Los índices de consistencia interna de la puntuación total y las subescalas fueron elevados (entre .93 y .96). La correlación significativa entre estos factores con variables personales arrojó pruebas sobre la validez concurrente de la escala.

Correspondence: Nissa Yaing Torres Soto, Medical Sciences Dept., Division of Health Sciences, University of Quintana Roo, Erick Paolo Martínez avenue, 77039 Chetumal, Quintana Roo, México. Email: nissa.torres@uqroo.edu.mx 
PALABRAS CLAVE: conductas de autocuidado, autocuidado físico, autocuidado psicológico, autocuidado espiritual.

\section{Introduction}

Self-care behaviors refer to a set of skills that the individual develops to preserve their own life, health, and well-being (Orem, 2001). It constitutes an ethical, moral and conscious commitment that allows for controlling health conditions, regulating human functioning and development (Richard and Shea, 2011). This term has been examined from different disciplinary fields, mostly developed in health literature (Godfrey et al., 2011; Lommi, Matarese, Alvaro, Piredda and De Marinis, 2015). Most studies have focused on evaluating self-care in clinical patients (Gao et al., 2013; Shrivastava, Shrivastava and Ramasamy, 2013), in older adults (CamposGarcía, Oliver, Tomás, Galiana and Gutiérrez, 2018; Jung, Kim, Bishop, and Hermann, 2019) and in public health professionals (Magno, 2020; Unadkat and Farquahar, 2020). Recently, psychology has examined the role of self-care in promoting well-being and psychological health, particularly in mental health professionals (Dorociak, Rupert, Bryant and Zahniser, 2017; Jiang, Topps and Suzuki, 2020; Posluns and Lynn, 2020). Evidence suggest people who practice self-care behaviors understand that such actions not only bring positive benefits to personal well-being, but also provide prosocial development (altruistic, equitable) and proenvironmental (frugal, pro-ecological) behaviors (Corral-Verdugo, Pato and TorresSoto, 2021). This literature highlights the importance of studying self-care to elucidate behaviors related to physical and mental health.

Research indicates the existence of a three-dimensional structure of self-care constituted by physical (body), interior (mind) and social (interpersonal relationships) self-care (Campos-García, et al., 2018; Galiana, Oliver, Sansó and Benito, 2015) conversely, from a theoretical perspective, Corral, Caso and Frías (2017) argue that self-care is primarily composed of three dimensions (physical, psychological, and spiritual).

Physical self-care involves a set of skills that are used to improve physical functioning and prevent or control disease. The vital processes of the body require water consumption, access to clean air, health protection, regular medical checkups, access to health care resources, and the avoidance body harm (Butler, Mercer, McClain-Meeder, Horne and Dudley, 2019; Corral et al., 2017). Maintaining a healthy diet, personal hygiene habits, physical exercise, sleep hygiene and recreational activities are some examples of physical self-care actions (Galiana, Oliver, Sansó and Benito, 2015; Harrison and Westwood 2009; Hernández, 2016).

Psychological self-care includes practices that lead to a better functioning of mental health allowing to face emotional conditions of anguish or alterations in life (Vidal-Blanco, Oliver, Galiana and Sansó, 2019). It represents an essential practice to prevent the mismanagement of stressful situations, exhaustion and personal deterioration (Barnett, Baker, Elman and Schoener, 2007). Previous studies show that the psychological self-care deficit is related to high levels of burnout, symptoms 
of stress and a greater risk of deteriorating health (Butler, Carello and Maguin, 2017; Santana and Fouad, 2017).

Spiritual self-care refers to how people relate to their subjectivity, including the belief in relationships with others, the existential connection that is established with a higher entity, and the feeling of being connected to the world (White, Peters and Schim, 2011). This is influenced by dispositions towards spirituality and is useful to motivate people to establish positive and reciprocal relationships with others, rebuild relationships and / or participating as volunteers in mutual help groups (Liu et al., 2008). Spiritual self-care also implies getting in touch with spirituality through the development of activities such as prayer, meditation, mindfulness, yoga and Tai Chi, getting in touch with nature, as well as participating in religious or self-help groups (Puchalski et al., 2019; Steinhorn, Din and Johnson, 2017; White and Myers, 2013; Butler, et al., 2019). It has been documented that participating in spiritual practices brings benefits to physical and mental health, especially in adulthood (Barreto et al., 2015; Koenig, 2018). This can be through its moderating role between occupational stress and emotional exhaustion (Chirico, Sharma, Zaffina and Magnavita, 2020; Rushton, Batcheller, Schroeder and Donohue, 2015).

Self-care appears to have specific advantages in physical health, it also appears to act as a protective factor for psychological well-being. Empirical evidence has demonstrated that physical self-care reduces symptoms of anxiety, stress, pain, depression, and sleep-related problems (Anderson, King, Stewart, Camacho, \& Rejeski, 2005; Callaghan, 2004; Gerber, Jonsdottir, Lindwall, and Ahlborg, 2014). Other studies have shown that increasing the frequency of physical exercise has important benefits to mental health, since it helps and prevents mental illnesses and contributes significantly to well-being (Mandolesi et al., 2018) as, optimism represents a significant predictor of physical health (Rasmussen, Scheier, \& Greenhouse, 2009).

Currently, there are some measures designed to evaluate self-care practices (Cook-Cottone and Guyker, 2018; Dorociak et al., 2017; Jiang, et al., 2020; Lee, Miller, \& Bride, 2020); however, there is a lack of studies that jointly evaluate physical, psychological and spiritual self-care. For this reason, it is pertinent to conduct an empirical verification of the trifactorial structure of self-care. Based on the previous approaches, the objective of this study was to design and validate a scale of self-care behaviors composed of three integrated in a Mexican sample.

\section{Method}

\section{Participants}

The sample was randomly selected using the formula for known population (confidence coefficient $=1.96$; probability of success $=.05$; margin of error $=.05$ ) (Fahim \& Negida, 2019). It included 235 participants from a city in northwestern Mexico, whose main characteristics are included in Table 1. 
Table 1

Descriptive statistics of the sociodemographic variables of the participants ( $N=235$ )

\begin{tabular}{|c|c|c|c|c|c|}
\hline Variable & $n$ & $\%$ & Variable & $n$ & $\%$ \\
\hline Gender & & & Religion & & \\
\hline Female & 144 & 61.3 & Catholic & 185 & 78.7 \\
\hline Male & 91 & 38.7 & Christian & 16 & 6.8 \\
\hline Age range & & & Buddhist & 2 & 0.9 \\
\hline $18-29$ & 96 & 40.9 & Jehovism & 2 & 0.9 \\
\hline $30-49$ & 55 & 23.4 & Jewish & 2 & 0.9 \\
\hline $50-69$ & 84 & 35.7 & Evangelical & 3 & 1.3 \\
\hline Weight (Kg) & & & Adventist & 1 & 0.4 \\
\hline $45-65$ & 97 & 41.3 & Atheist & 24 & 10.2 \\
\hline $66-86$ & 93 & 39.6 & Type of disease & & \\
\hline $87-107$ & 36 & 15.3 & None & 183 & 77.9 \\
\hline $108-128$ & 7 & 3.0 & Obesity & 26 & 11.1 \\
\hline $129-150$ & 2 & 0.9 & Arterial Hypertension & 5 & 2.1 \\
\hline Scholarship & & & Nutritional deficiency & 5 & 2.1 \\
\hline None & 9 & 3.8 & Heart disease & 5 & 2.1 \\
\hline Elementary & 3 & 1.3 & Diabetes & 5 & 2.1 \\
\hline High school & 15 & 6.4 & Arthritis & 4 & 1.7 \\
\hline Technical career & 30 & 12.8 & Others & 2 & 0.9 \\
\hline University & 135 & 57.4 & Sports activities & & \\
\hline Postgraduate & 43 & 18.3 & None & 57 & 24.3 \\
\hline Monthly family income & & & Once a week & 47 & 20.0 \\
\hline$\leq \$ 2,500$ & 1 & 4.0 & 2-3 times a week & 68 & 28.9 \\
\hline$\$ 2.501$ a $\$ 5.000$ & 65 & 27.7 & $>3$ times a week & 63 & 26.8 \\
\hline$\$ 5.0001$ a $\$ 1.000$ & 65 & 27.7 & Tobacco & & \\
\hline$\$ 1.001$ a $\$ 2.000$ & 67 & 28.5 & Never & 190 & 80.9 \\
\hline$\$ 2.001$ a $\$ 4.000$ & 5 & 2.1 & Once a week & 16 & 6.8 \\
\hline$\geq \$ 4.0001$ & 32 & 13.6 & 2-3 times a week & 11 & 4.7 \\
\hline Marital status & & & $>4$ times a week & 2 & 0.9 \\
\hline Married & 109 & 46.4 & Everyday & 16 & 6.8 \\
\hline Single & 95 & 40.4 & Alcoholic beverages & & \\
\hline Divorced & 11 & 4.7 & Never & 129 & 54.9 \\
\hline Free union & 20 & 8.5 & Once a week & 86 & 36.6 \\
\hline Medical service & & & 2-3 times a week & 17 & 7.2 \\
\hline $\mid \mathrm{NSAB|}$ & 75 & 31.9 & $>4$ times a week & 2 & 0.9 \\
\hline IMSS & 73 & 31.1 & Everyday & 1 & 0.4 \\
\hline ISSSTE & 64 & 27.2 & & & \\
\hline None & 23 & 9.8 & & & \\
\hline
\end{tabular}

Note: INSABI= Instituto de Salud para el Bienestar [Institute of Health for Wellbeing]; IMSS= Instituto Mexicano del Seguro Social [Mexican Institute of Social Secure]; ISSSTE= Instituto de Seguridad y Servicios Sociales de los Trabajadores del Estado [Institute of Social Security and Services for State Employees].

\section{Instruments}

a) Sociodemographic questionnaire ad hoc. The following sociodemographic data were also collected by the time of instrument application: age, income, 
education, body weight, other health concern, consumption of alcohol and tobacco, access to medical services, practice of sporting activities and involvement in religious activities.

b) Self-Care Behaviors (CA). scale is made up of 52 items that measures three dimensions of self-care: physical (20 items), psychological (23 items) and spiritual (9 items) of 5 Likert-scale response options ( $1=$ never, $2=$ almost never, $3=$ occasionally, $4=$ almost always to $5=$ always) (see Appendix). This questionnaire initially included 61 items distributed as follows in the three dimensions of self-care: physical (29 items), psychological (23 items) and spiritual ( 9 items). The self-care behavior scale "Care with yourself" by CorralVerdugo, et al. (2021) served as a reference. For 18 items answered on a Likerttype scale ( $0=$ never to $4=$ every day). The original scale was applied in a sample like that of the present study, presenting a high Cronbach's alpha $(\alpha=.94)$ and with significant factor loadings between items $(p<.05)$ ranging between .58 and .82 during the optimization of the confirmatory factor analysis (CorralVerdugo et al., 2021). This evaluates behaviors such as physical exercise, eating healthy foods, promoting positive emotions, maintaining positive relationships with others, and practicing meditation. A first exercise involved expanding the number of original items without losing the theoretical content that supports the construct and self-care classifying behaviors (physical, psychological, and spiritual). For the Psychological Self-Care subscale, 11 items were created based on the "Perceived emotional intelligence scale" (Trait Meta-Mood Scale TMMS24) by Salovey, Mayer, Goldman, Turvey, \& Palfai (1995) adapted to Spanish by Fernández-Berrocal, Extremera, \& Ramos (2004) that measures metaknowledge of emotional states through 24 items grouped in three dimensions: attention to emotions ( $\alpha=.80)$, emotional clarity $(\alpha=.75)$ and emotional repair $(\alpha=.74)$ and with a Conbach's alpha of .83 for the total scale. The "Spiritual Self-care Practices Scale" was taken as a reference for the subscale of Spiritual Self-Care, eight items were created (White, 2016). For the Spiritual Self-Care subscale, the "Spiritual Self-care Practices Scale" (White, 2016) was used as a reference. The scale is composed of 35 items grouped into four dimensions: personal care practices $(\alpha=.89)$ with 14 items that allow actions such as having time for myself, eating healthy foods, feeling at peace and/or at harmony, resting, giving love, following medical orders, maintaining a sense of hope for the future, laughing, forgiveness, finding meaning in life, maintaining positive relationships, asking questions about medical orders and helping other people. The component of Spiritual Practices $(\alpha=.85)$ there are 9 items that include actions such as attending religious services, contributing to a religious group, praying, consulting a spiritual counselor, living a moral life, meditating, contemplating, or reflecting, reading to search for inspiration, repairing broken relationships and resolve conflict resolution. The component of physical spiritual practices $(\alpha=.69)$ is comprised of 5 items that allow for participation in physical activities, giving alms or performing other acts of charity, participating as a volunteer, hiking, and practicing yoga or tai-chi. Finally, in interpersonal spiritual practices $(\alpha=.66)$ with 7 items that analyze the follow-up of a special diet, 
friendships, spend time with family and friends, have a meaningful conversation with others and receive love. The internal consistency index (Cronbach's alpha coefficient) for the full scale was high $(\alpha=.91)$, which indicates scale reliability. The selected items for the sub-scale of spiritual self-care were chosen from these domains.

\section{Procedure}

The survey was designed using Qualtrics software and shared through social networks and websites. Prior to participation, consent was obtained and participants were informed of the anonymous, confidential and voluntary nature of their involvement and the protection of their. All procedures were approved by the Ethics Committee of the University of Sonora (CEI-UNISON).

\section{Data analysis}

The normality of the data was evaluated by testing skewness and kurtosis. Univariate statistics were obtained, and reliability analysis (Cronbach's alpha) was performed using SPSS software version 21. Using this same statistical package, an exploratory factor analysis (EFA) was developed. The principal components analysis was used since it allows to extract a maximum variance for each factor and preserves as much variability as possible (Chen, Chen, \& Jin, 2011). Additionally, the Varimax rotation was used, taking as inclusion criteria items with factorial weight $\geq .40$ (Pituch \& Stevens, 2016). The KMO index (Kaiser-Meyer-Olkin measure of sampling adequacy) and Bartlett's test of sphericity (Field, 2013) were tested.

A covariance model was specified and tested, within a confirmatory factor analysis, using the statistical package EQS, to estimate validity (Bentler, 2006). Given the number of items the relatively small sample to estimate structural equation models, three plots were computed for each factor (Hau \& Marsh, 2004). The statistical goodness of fit indices used in this model were the chi-square, as well as the practical goodness of fit indices: Bonett of Normed Fit (BBNFI) and the BentlerBonett Index of Non-Normed Fit (BBNNFI), in addition to the RMSEA allowing to consider the relevance of the model (O'Boyle \& Williams, 2011).

The test of the average variance extracted (AVE) was performed, as well as the square root of average variance extracted (Sqrt AVE) based on the assumptions of Hair, Black, Babin, Anderson, \& Tatham (2009), to measure convergent and divergent validity. To calculate the AVE, the factorial weights of each factor $(\lambda)$ were extracted, squared, added and divided by the total number of indicators. Sqrt AVE was calculated obtaining the square root of the AVE (convergent validity: AVE> .50; divergent validity Sqrt AVE $>$ value of the covariances between the factors) (Henseler, Ringle, \& Sinkovics, 2009). Finally, to obtain indicators of concurrent validity, a Pearson correlation matrix was computed to observe the interrelationships between self-care factors and sociodemographic characteristics. 


\section{Results}

\section{Exploratory factor analysis}

The factorial structure presented three dimensions explaining $54.18 \%$ of the total variance, with a high index of internal consistency $(\alpha=.95)$. The sample adequacy measure $(\mathrm{KMO}=.90)$ and Bartlett's sphericity test were acceptable $(14511,12 ; p<.001)$. Both values indicated an adequate adjustment of the factorial analysis for the set of items (Table 2 ). It is important to note that items with $\lambda<.40$ were eliminated, resulting in nine items of the physical self-care component $(4,5$, $9,11,17,18,19,22,28)$ being eliminated. This resulted in a total of 52 items for the final self-care scale, divided into three subscales (physical self-care $=2$, psychological self-care $=23$, spiritual self-care $=9)$. The communality statistics $\left(\eta^{2}\right)$ were higher than .50 (or 67\%), which demonstrated that the factorial solution managed to explain high proportions of variance for each item subjected to validation.

\section{Table 2}

Means, standard deviations, rotated factor saturations and communalities $\left(\eta^{2}\right)$ for the items of the self-care factors

\begin{tabular}{|c|c|c|c|c|c|c|}
\hline \multirow{2}{*}{ Ítems } & \multirow{2}{*}{ M } & \multirow{2}{*}{$S D$} & \multicolumn{3}{|c|}{ Factor saturations } & \multirow{2}{*}{$\eta^{2}$} \\
\hline & & & 1 & 2 & 3 & \\
\hline 1. I do some kind of physical activity. & 3.64 & 0.80 & .795 & .013 & .018 & .633 \\
\hline 2. I try to eat healthy foods. & 3.80 & 0.82 & .828 & .179 & -.002 & .718 \\
\hline $\begin{array}{l}\text { 3. I use to alternate the position of my body } \\
\text { throughout the day to preserve my health. }\end{array}$ & 3.77 & 0.79 & .775 & .046 & .034 & .604 \\
\hline $\begin{array}{l}\text { 6. I frequently examine my body to see if there } \\
\text { are any changes. }\end{array}$ & 3.78 & 0.80 & .873 & .113 & .052 & .777 \\
\hline 7. I moderate the use of salt in my diet. & 3.69 & 0.96 & .745 & .044 & .077 & .563 \\
\hline 8. I get enough sleep to feel rested. & 3.68 & 0.95 & .761 & .036 & .088 & .589 \\
\hline $\begin{array}{l}\text { 10. I make changes in my eating habits to keep } \\
\text { control of my weight }\end{array}$ & 3.77 & 0.93 & .736 & .081 & .060 & .551 \\
\hline $\begin{array}{l}\text { 12. I make changes to my bad habits to } \\
\text { maintain my health. }\end{array}$ & 3.82 & 0.81 & .783 & .141 & -.009 & .633 \\
\hline $\begin{array}{l}\text { 13. I attend periodic medical check-ups to } \\
\text { maintain my health. }\end{array}$ & 3.78 & 0.83 & .830 & .122 & -.002 & .704 \\
\hline $\begin{array}{l}\text { 14. Before taking a medicine, I get all the } \\
\text { information about the harmful effects on my } \\
\text { health. }\end{array}$ & 3.80 & 0.83 & .833 & .131 & -.004 & .711 \\
\hline $\begin{array}{l}\text { 15. I try not to self-medicate when I have pain } \\
\text { or illness. }\end{array}$ & 3.71 & 0.86 & .827 & .094 & .083 & .700 \\
\hline $\begin{array}{l}\text { 16. I make changes in my habits to maintain my } \\
\text { weight. }\end{array}$ & 3.83 & 0.97 & .719 & .140 & -.011 & .536 \\
\hline $\begin{array}{l}\text { 20. I maintain personal hygiene practices every } \\
\text { day (dental hygiene, hand washing, bathing, } \\
\text { cutting nails, etc.). }\end{array}$ & 3.87 & 0.88 & .813 & .079 & .110 & .679 \\
\hline 21. I try to brush my teeth three times a day. & 3.98 & 0.87 & .801 & .075 & .113 & .660 \\
\hline
\end{tabular}




\begin{tabular}{|c|c|c|c|c|c|c|}
\hline \multirow{2}{*}{ Ítems } & \multirow{2}{*}{ M } & \multirow{2}{*}{$S D$} & \multicolumn{3}{|c|}{ Factor saturations } & \multirow{2}{*}{$\eta^{2}$} \\
\hline & & & 1 & 2 & 3 & \\
\hline 23. I try to bathe daily. & 4.12 & 0.87 & .668 & .043 & .149 & .470 \\
\hline 24. I keep my nails short and clean. & 3.94 & 0.85 & .715 & .096 & .021 & .520 \\
\hline 25. I rest to regain my health and energy. & 4.00 & 0.87 & .757 & .101 & .100 & .593 \\
\hline $\begin{array}{l}\text { 26. I consume at least three meals a day } \\
\text { (breakfast, lunch and dinner). }\end{array}$ & 4.02 & 0.86 & .646 & .100 & .128 & .444 \\
\hline 27. I eat a balanced diet to maintain my health. & 3.92 & 0.90 & .708 & .031 & .088 & .510 \\
\hline $\begin{array}{l}\text { 29. I avoid consuming foods that harm my } \\
\text { health (fats, salts, sausages, sweets, soda, etc.). }\end{array}$ & 3.96 & 0.92 & .750 & .133 & .070 & .585 \\
\hline 30. I usually worry a lot about how I feel. & 3.81 & 1.00 & .074 & .614 & -.015 & .383 \\
\hline $\begin{array}{l}\text { 31. I usually spend time thinking about my } \\
\text { emotions. }\end{array}$ & 3.77 & 1.07 & .077 & .639 & -.012 & .414 \\
\hline 32. I often think about my feelings. & 3.81 & 1.06 & .048 & .596 & .043 & .360 \\
\hline $\begin{array}{l}\text { 33. I think my emotions and mood are worth } \\
\text { paying attention to. }\end{array}$ & 4.17 & 0.95 & .003 & .625 & .065 & .394 \\
\hline 34. I try to be in a good mood. & 4.20 & 0.87 & .012 & .668 & .092 & .454 \\
\hline $\begin{array}{l}\text { 35. When I am sad, I think of all the pleasures } \\
\text { in life. }\end{array}$ & 3.54 & 1.15 & .089 & .534 & .159 & .318 \\
\hline $\begin{array}{l}\text { 36. Although sometimes I feel sad, I usually } \\
\text { have an optimistic vision. }\end{array}$ & 3.98 & 0.98 & .058 & .531 & .187 & .320 \\
\hline $\begin{array}{l}\text { 37. I do activities to rest from daily worries } \\
\text { (read a book, do sports, go for a run, among } \\
\text { others). }\end{array}$ & 3.93 & 1.02 & .085 & 616 & .030 & .387 \\
\hline 38. I take the time to do things that I like. & 4.09 & 0.90 & .088 & .678 & .047 & .469 \\
\hline $\begin{array}{l}\text { 39. I try to maintain a balance between my } \\
\text { body, my emotions and my mind. }\end{array}$ & 3.90 & 0.90 & .232 & .731 & .168 & .616 \\
\hline $\begin{array}{l}\text { 40. I participate in activities that help me to be } \\
\text { a better person. }\end{array}$ & 3.92 & 0.96 & .160 & .649 & .248 & .508 \\
\hline 41. I do activities that generate well-being. & 3.96 & 0.90 & .140 & .748 & .097 & .588 \\
\hline 42. I try to get to know myself better every day. & 3.97 & 0.97 & .113 & .732 & .162 & .575 \\
\hline 43. I do things that give me pleasure. & 4.07 & 0.87 & .161 & .765 & .021 & .612 \\
\hline $\begin{array}{l}\text { 44. I enjoy maintaining healthy relationships } \\
\text { with others. }\end{array}$ & 4.49 & 0.67 & .001 & .524 & .059 & .278 \\
\hline 45. Every day I try to be at peace with myself. & 4.29 & 0.83 & -.016 & .686 & .138 & .490 \\
\hline $\begin{array}{l}\text { 46. After work (or study) I try to reward myself } \\
\text { with any pleasant activity. }\end{array}$ & 4.05 & 0.96 & .033 & .628 & .127 & .412 \\
\hline $\begin{array}{l}\text { 47. When I perceive that I am stressed, I try to } \\
\text { think of other things. }\end{array}$ & 3.80 & 1.00 & .016 & .538 & .152 & .313 \\
\hline $\begin{array}{l}\text { 48. Even if I feel bad, I try to think of pleasant } \\
\text { things. }\end{array}$ & 3.94 & 0.93 & -.002 & .625 & .146 & .412 \\
\hline $\begin{array}{l}\text { 49. I try to think positive thoughts, even if I feel } \\
\text { bad. }\end{array}$ & 4.03 & 0.97 & .008 & .549 & .220 & .349 \\
\hline $\begin{array}{l}\text { 50. I am aware of my feelings in different } \\
\text { situations. }\end{array}$ & 4.20 & 0.79 & -.043 & .693 & .061 & .485 \\
\hline 51. I know well how I feel. & 4.04 & 0.90 & 101 & .733 & .057 & .550 \\
\hline $\begin{array}{l}\text { 52. To keep my mind relaxed and calm, I do } \\
\text { activities that help me feel better. }\end{array}$ & 4.02 & 0.90 & .130 & .701 & .164 & .535 \\
\hline 53. I experience satisfaction after meditating. & 2.91 & 1.35 & .075 & 236 & .668 & .508 \\
\hline
\end{tabular}




\begin{tabular}{|c|c|c|c|c|c|c|}
\hline \multirow{2}{*}{ Ítems } & \multirow{2}{*}{ M } & \multirow{2}{*}{$S D$} & \multicolumn{3}{|c|}{ Factor saturations } & \multirow{2}{*}{$\eta^{2}$} \\
\hline & & & 1 & 2 & 3 & \\
\hline $\begin{array}{l}\text { 54. I turn to meditation to find inner peace and } \\
\text { strength. }\end{array}$ & 2.97 & 1.35 & .055 & .252 & .583 & .406 \\
\hline $\begin{array}{l}\text { 55. I practice spiritual activities to find harmony } \\
\text { with the world. }\end{array}$ & 2.86 & 1.37 & .036 & .255 & .730 & .600 \\
\hline $\begin{array}{l}\text { 56. I feel connected to a being greater than } \\
\text { myself (God). }\end{array}$ & 3.48 & 1.40 & .083 & .137 & .799 & .665 \\
\hline $\begin{array}{l}\text { 57. I practice spiritual practices to maintain my } \\
\text { health (yoga, tai chi, meditation, praying, } \\
\text { biblical coexistence groups, reading spiritual } \\
\text { texts, etc). }\end{array}$ & 2.79 & 1.41 & .041 & .169 & .756 & .602 \\
\hline $\begin{array}{l}\text { 58. My relationship with a higher being (God) } \\
\text { helps me to love others. }\end{array}$ & 3.51 & 1.34 & .088 & .062 & .886 & .797 \\
\hline 59. I have learned to forgive other people. & 3.57 & 1.30 & .097 & .060 & .869 & .768 \\
\hline 60. I have learned to forgive myself. & 3.60 & 1.30 & .084 & .079 & .873 & .776 \\
\hline $\begin{array}{l}\text { 61. I seek comfort through spiritual means } \\
\text { (prayer, meditation, attending religious or } \\
\text { spiritual services, or taking spiritual counseling). }\end{array}$ & 3.08 & 1.45 & .072 & .188 & .784 & .655 \\
\hline
\end{tabular}

Note: Factor 1= Physical self-care; Factor 2= Psychological self-care; Factor 3= Spiritual self-care.

Factor 1 referred to as Physical self-care was made up of 20 items that consist of personal care actions that people do to take care of their bodies. This factor presented $28.33 \%$ of the total explained variance and its level of internal consistency (Cronbach's alpha) was high of .96. Factor 2, named psychological self-care, was made up of 23 items that refer to the perception that people have regarding emotional regulation and personal satisfaction. This factor presented $16.89 \%$ of total explained variance and its level of internal consistency (Cronbach's alpha) was high at .94. Finally, factor 3, called Spiritual self-care, was made up of 9 items referring to the inner peace that a person maintains by being connected with their spirit, body and soul. This factor explains $8.95 \%$ of the total variance and its level of internal consistency (Cronbach's alpha) was high of .93.

Physical self-care was correlated in a moderately low and significant way with psychological self-care $(r=.23)$, while psychological self-care was positively, moderately, and significantly related to spiritual self-care $(r=.35)$; the association between physical self-care and spiritual self-care was low but, significant $(r=.18)$. Inversely, age and income were positively associated with each subscale, while body weight was negatively associated with physical self-care only. Having health care services, practicing some kind of sporting activity, access to health services and being religious were positively related to the three dimensions. Living with some kind of disease and, the consumption of tobacco and alcohol were negatively and significantly associated with the three behaviors. Finally, scholarship was not related to any type of self-care behavior (Table 3). 
Table 3

Correlation matrix between sociodemographic and self-care characteristics

\begin{tabular}{|c|c|c|c|}
\hline Variables & Physical self-care & Psychological Self-care & Spiritual Self-care \\
\hline Physical self-care & 1 & & \\
\hline Psychological Self-care & $.23 * \star$ & 1 & \\
\hline Spiritual Self-care & $.18 * \star$ & $.35 * \star$ & 1 \\
\hline Age & $.16^{\star}$ & $.51 * \star$ & $.75 * \star$ \\
\hline Weight & $-.13 *$ & -.12 & -.11 \\
\hline Scholarship & .11 & .03 & -.01 \\
\hline Income & $.20 * *$ & $.20 * *$ & $.15^{*}$ \\
\hline Ilness or disease & $-.20 * \star$ & $-.24 * \star$ & $-.33 * \star$ \\
\hline Medical assistance & $.23 * \star$ & $.28 * \star$ & $.22 * \star$ \\
\hline Sports activities & $21 * *$ & $22^{* *}$ & $.32 * *$ \\
\hline Medical service & $22 * \star$ & $30 * \star$ & $.24 * \star$ \\
\hline Religion & $.20 * \star$ & $.24 * \star$ & $.36 * \star$ \\
\hline Tobacco & $-.22 * \star$ & $-.36^{* *}$ & $-.35^{\star *}$ \\
\hline Alcohol & $-.21 * \star$ & $-.27 * \star$ & $-.32 * \star$ \\
\hline
\end{tabular}

Note: ${ }^{*} p<.05 ;{ }^{* *} p<.01$.

Figure 1 shows the results of the model in which the factors of physical selfcare, psychological self-care and spiritual self-care emerge in a coherent way from the high and significant relationships between their indicators (parcels). The three covariances were significant $(p<.05)$. Regarding the goodness of fit indicators of the model, the $\chi^{2}$ was not significant $\left(\chi^{2}[24]=35.28 ; p>.05\right)$ and the practical indicators (BBNFl= .98; $\mathrm{BBNNFI}=.99 ; \mathrm{CFl}=.99)$ as well as the RMSEA $=.04$ indicate that the theoretical model adequately fits the empirical data. 
Figure 1

Covariance model of self-care factors

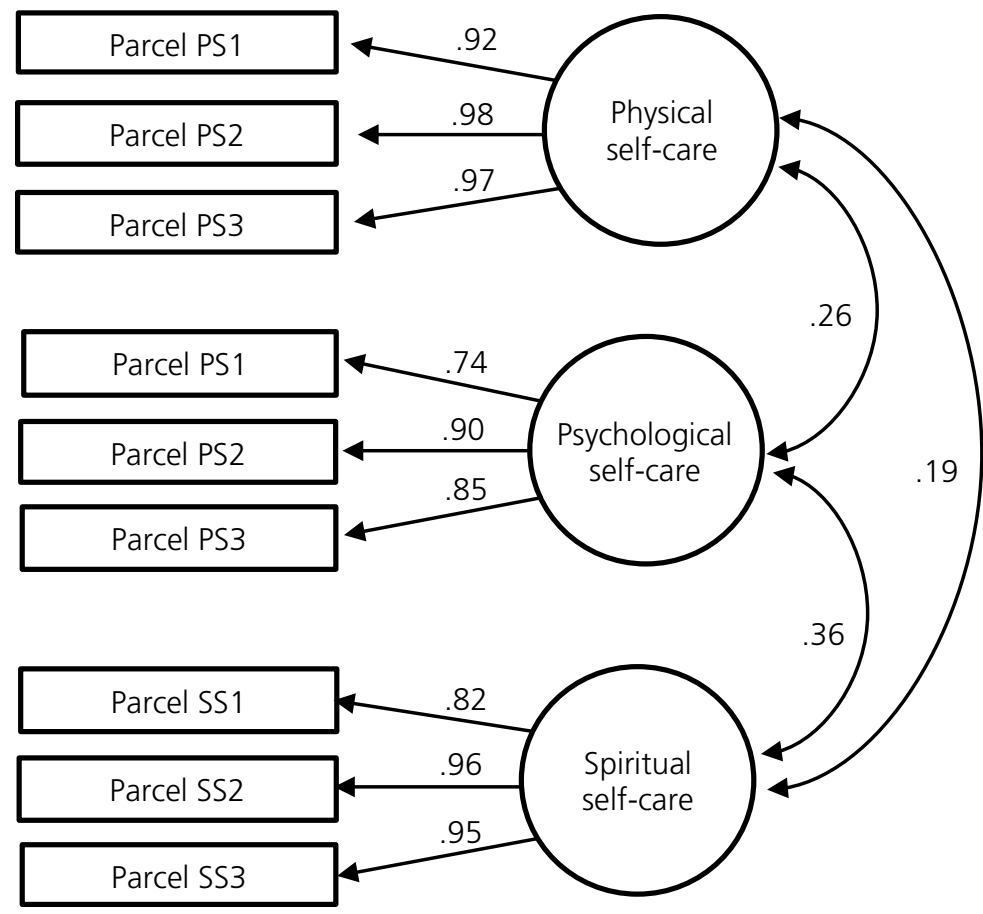

Notes: $\mathrm{AF}=$ Physical self-care, $\mathrm{AP}=$ Psychological self-care, $\mathrm{AE}=$ Spiritual self-care

The lambdas of the three self-care factors were acceptable $(.74<\lambda<.98)$. The AVE of each subscale were greater than .50 and the difference between Sqrt AVE and the covariances were positive. Therefore, in the model of self-care factors they suggest both convergent and divergent validity (Tables 4 and 5).

Table 4

Average variance extracted (AVE) and square root of average variance extracted for self-care \begin{tabular}{|l|c|c|}
\multicolumn{1}{|c|}{ Scales } \\
\hline Self-care scales & AVE & Sqrt AVE \\
\hline Physical Self-care & .91 & .95 \\
\hline Psychological Self-care & .69 & .83 \\
\hline Spiritual Self-care & .83 & .91 \\
\hline
\end{tabular}

Note: AVE: average variance extracted; Sqrt AVE: square root of average variance extracted 
Table 5

Difference between the square root of average variance extracted and covariances for the self-care scales

\begin{tabular}{|l|c|}
\hline \multicolumn{1}{|c|}{ Self-care scales } & $\begin{array}{c}\text { Difference Sqrt AVE - } \\
\text { covariance }\end{array}$ \\
\hline Physical self-care - Psychological self-care & .698 \\
\hline Physical self-care - Spiritual self-care & .770 \\
\hline Psychological Self-care - Physical Self-care & .698 \\
\hline Psychological Self-care - Spiritual Self-care & .471 \\
\hline Spiritual Self-care - Physical Self-care & .728 \\
\hline Spiritual Self-care - Psychological Self-care & .551 \\
\hline
\end{tabular}

Note: Sqrt AVE: square root of average variance extracted

\section{Discussion}

The results of the present study demonstrate that the "Self-Care Behavior Scale" (CA) exhibited adequate psychometric properties. Its factorial structure revealed the existence of three factors, called physical, psychological and spiritual self-care, presenting acceptable internal consistency indices for both the total instrument and the subscales. The statistics showed that the instrument evaluates a congruent construct. The full self-care scale demonstrates high internal consistency. Likewise, the confirmatory factor analysis has high lambda values indicating convergent construct validity. The scale also demonstrated discriminant validity between the three dimensions of self-care. The covariances between the factors were lower than the lambdas values between the factors and their indicators, which is considered evidence of divergent validity (Corral \& Figueredo, 1999). The values of the average variance extracted (AVE) and the square root of average variance extracted (Sqrt AVE) corroborated the presumption of convergent and divergent validity of the self-care measure.

As predicted, the self-care factors were positively and significantly correlated with each other. Despite the lack of studies in this area, some studies report that people who practice physical self-care behaviors understand that these actions allow them to positively impact their emotional and spiritual health (Lustyk, Widman, Paschane, \& Olson, 2004; White \& Myers, 2013). It is worth mentioning that those people who maintain physical care practices have greater emotional regulation skills and better skills to handle stressful and exhausting situations (Anderson et al., 2005; Callaghan, 2004; Sansó et al., 2015). These results, in congruence with the literature, suggest that taking care of oneself physically is related to improvements in emotional and spiritual aspects.

On the other hand, emotional self-care can have a positive influence on practices that impact physical health. Some studies maintain that the greater selfawareness and personal satisfaction, the greater the deployment of physical activities that positively affect people's health and well-being (Babakhani, 2011). In this way, it is evident that psychological self-care is an essential requirement for people to be able to assume healthy lifestyle habits and maintain good physical health. 
Our findings showed a higher association between psychological self-care and spiritual self-care in congruence with results presented by Bloomquist, Wood, Friedmeyer-Trainor, and Kim (2015). A person who has learned to self-regulate their emotions has a greater awareness of their own human needs and a greater capacity to maintain and promote spiritual actions (Myers et al., 2012). Previous research has shown that self-awareness has a direct effect on emotional regulation, and this, in turn, positively impacts spiritual self-care and well-being (Richards, Campenni, \& Muse-Burke, 2010). It has been found that this relationship works reciprocally, since mindfulness can have a positive effect on psychological self-care (Brown \& Ryan, 2003) and contributes to the general well-being of people, acting as a protective factor of physical, mental and emotional health (Valiente-Barroso, Sáiz-Obeso, \& Martínez-Vicente, 2021). Likewise, people with good emotional self-regulation have greater possibilities of taking care of their spirituality through actions such as meditation, yoga, inner peace, among others (White \& Myers, 2013). These actions positively impact physical and emotional health (Parsian \& Dunning, 2009). The above suggests a health model with organic, emotional and spiritual implications.

Consistent with research that shows lower levels of healthy practices in the young population, our results produced a positive correlation between age and selfcare (Fortuna, Robbins, \& Halterman, 2009). Economic income also had a negative relationship, suggesting that a better economic affluence results in better access to services (i.e., doctors, gym, nutrition). These findings have been documented in previous research positing that income conditions self-care behaviors (Walker, Gebregziabher, Martin-Harris, \& Egede, 2014; Yee, McGuire, Taylor, Niznik, \& Simon, 2015). Similar to previous research, individuals who suffer from illness and/or consume harmful substances were negatively correlated with individual self-care (Rodríguez-Muñoz, Carmona-Torres, \& Rodríguez-Borrego, 2020).

The literature supports that religious practice and spirituality can increase selfcare practices (Heidari, Rezaei, Sajadi, Ajorpaz, \& Koenig, 2017; Sharif Nia et al., 2017) and physical and mental health (Goudarzian et al., 2019; Koenig, 2015). In the same way, systematic research supports the argument that religious and spiritual participation has positive effects on emotional health (Koenig, 2009), since it contributes to well-being, personal flourishing and prosperity (Park \& Slattery, 2013). Additionally, religiosity is related to physical activity, a balanced diet, safe sexual practices and a lower consumption of harmful substances (Jim et al., 2015; Koenig, 2015; Koenig, 2012). All these results highlight the importance of educating the population to maintain self-care practices in a conscious and reasoned way, not only to improve health and prevent diseases, but also to positively impact well-being. This is especially relevant given the current proliferation of conditions of chronic degenerative diseases and communicable infections.

The present study has some limitations. Self-care was evaluated through selfreport, a technique subject to a certain degree of subjectivity and social desirability. Although the use of alternative measures is more complex and less convenient, future studies could use alternative methods. This could include the implementation of specific self-care strategies, through an experimental design to make comparisons with controlled groups. It would be advisable to develop longitudinal studies to evaluate the stability and fit of the self-care model. Another limitation is that the 
scale was applied during the initial months of the Covid-19 pandemic, which could represent a possible exacerbation of self-care behaviors. Finally, this study was conducted on a sample from northwestern Mexico, which makes it difficult to generalize the results to other Mexican or Latin American contexts. Further studies are needed in a wide variety of sociocultural contexts.

Despite these limitations, this research provides an important contribution to the study of self-care behavior and its association with health and wellbeing. All three dimensions could be used for future research, education, and public policy efforts, which in turn would benefit wellness and health holistically. In the case of this study, we focused on studying self-care in a general sample from a Mexican city; however, a suggestion for future studies would be to examine this construct in specific or vulnerable populations, such as analyzing the elderly population. This scale could be applied in the field of public health and examine populations with some type of disease to determine if the dimensions of self-care can mitigate the ravages of disease and improve well-being.

\section{References}

Anderson, R. T., King, A., Stewart, A. L., Camacho, F., \& Rejeski, W. J. (2005). Physical activity counseling in primary care and patient well-being: Do patients benefit? Annals of Behavioral Medicine, 30, 146-154. doi: 10.1207/s15324796abm3002_7

Barnett, J. E., Baker, E. K., Elman, N. S., \& Schoener, G. R. (2007). In pursuit of wellness: The self-care imperative. Professional Psychology: Research and Practice, 38, 603-612. doi: https://doi.org/10.1037/0735-7028.38.6.603

Barreto, P., Fombuena, M., Diego, R., Galiana, L., Oliver, A., \& Benito, E. (2015). Bienestar emocional y espiritualidad al final de la vida [Emotional well-being and spirituality at the end of life]. Medicina Paliativa, 22, 25-32. doi: 10.1016/j.medipa.2013.02.002

Bentler, P. M. (2006). EQS: Structural equations program manual (6 $6^{\text {th }}$ Ed.). Encino, CA: Multivariate Software.

Bloomquist, K. R., Wood, L., Friedmeyer-Trainor, K., \& Kim, H. W. (2015). Self-care and professional quality of life: Predictive factors among MSW practitioners. Advances in Social Work, 16, 292-311. doi: 10.18060/18760

Butler, L. D., Carello, J., \& Maguin, E. (2017). Trauma, stress, and self-care in clinical training: Predictors of burnout, decline in health status, secondary traumatic stress symptoms, and compassion satisfaction. Psychological Trauma: Theory, Research, Practice, and Policy, 9, 416-424. doi: 10.1037/tra0000187

Butler, L. D., Mercer, K. A., McClain-Meeder, K., Horne, D. M., \& Dudley, M. (2019). Six domains of self-care: Atending to the whole person. Journal of Human Behavior in the Social Environment, 29, 107-124. doi: 10.1080/10911359.2018.1482483

Callaghan, P. (2004). Exercise: A neglected intervention in mental health care? Journal of Psychiatric and Mental Health Nursing, H, 476-483. doi: 10.1111/j.13652850.2004.00751.x

Campos-García, A., Oliver, A., Tomás, J. M., Galiana, L., \& Gutiérrez, M. (2018). Self-care: New evidence for its measurement in older adults. Revista Española de Geriatría y Gerontología, 53, 326-331. doi: 10.1016/j.regg.2018.01.010

Chirico, F., Sharma, M., Zaffina, S., \& Magnavita, N. (2020). Spirituality and prayer on teacher stress and burnout in an Italian cohort: A pilot, before-after controlled study. Frontiers in Psychology, 10, 1-7. doi: 10.3389/fpsyg.2019.02933 
Cook-Cottone, C. P., \& Guyker, W. M. (2018). The development and validation of the Mindful Self-Care Scale (MSCS): An assessment of practices that support positive embodiment. Mindfulness, 9, 161-175. doi: 10.1007/s12671-017-0759-1

Corral, V., \& Figueredo, A. J. (1999). Convergent and divergent validity of three measures of conservation behavior: The multitrait-multimethod approach. Environment \& Behavior, 31, 805-820. doi: 10.1177/00139169921972353

Corral, V., Caso, J., \& Frías, M. (dirs.) (2017). Psicología del cambio climático. Mitigación y adaptación conductual ante el calentamiento global [Psychology of climate change. Mitigation and behavioral adaptation to global warming] (1 ${ }^{\text {st }}$ Ed.). Mexico: Pearson.

Corral-Verdugo, V., Pato, C., \& Torres-Soto, N. (2021). Testing a tridimensional model of sustainable behavior: Self-care, caring for others, and caring for the planet. Environment, Development and Sustainability, 1-16. doi: 10.1007/s10668-02001189-9

Dorociak, K. E., Rupert, P. A., Bryant, F. B., \& Zahniser, E. (2017). Development of the Professional Self-Care Scale. Journal of Counseling Psychology, 64, 325-334. doi: $10.1037 /$ cou0000206

Fahim, N. K., \& Negida, A. (2019). Sample size calculation guide-part 2: How to calculate the sample size for an independent cohort study. Advanced Journal of Emergency Medicine, 3, 1-2. doi: 10.22114/AJEM.v0i0.104s

Fernández-Berrocal, P., Extremera, N., \& Ramos, N. (2004). Validity and reliability of the Spanish modified version of the Trait Meta-Mood Scale. Psychological Reports, 94(3), 751-755. doi: 10.2466/pr0.94.3.751-755

Field, A. (dir.) (2013). Discovering statistics using IBM SPSS statistics. (4 ${ }^{\mathrm{a}}$ ed.) Londres: Sage.

Fortuna, R. J., Robbins, B. W. y Halterman, J. S. (2009). Ambulatory care among young adults in the United States. Annals of Internal Medicine, 151, 379-385. doi: 10.7326/00034819-151-6-200909150-00002

Galiana, L., Oliver, A., Sansó, N., \& Benito, E. (2015). Validation of a new instrument for selfcare in Spanish palliative care professionals nationwide. The Spanish Journal of Psychology, 18, 1-9. doi: 10.1017/SJP.2015.71

Gao, J., Wang, J., Zheng, P., Haardörfer, R., Kegler, M. C., Zhu, Y., \& Fu, H. (2013). Effects of self-care, self-efficacy, social support on glycemic control in adults with type 2 diabetes. BMC Family Practice, 14, 1-6. doi: 10.1186/1471-2296-14-66

Gerber, M., Jonsdottir, I. H., Lindwall, M., \& Ahlborg, G. (2014). Physical activity in employees with differing occupational stress and mental health profiles: A latent profile analysis. Psychology of Sport and Exercise. 15, 649-658. doi: 10.1016/j.psychsport.2014.07.012

Godfrey, C. M., Harrison, M. B., Lysaght, R., Lamb, M., Graham, I. D., \& Oakley, P. (2011). Care of self-care by other-care of other: The meaning of self-care from research, practice, policy and industry perspectives. International Journal of Evidence-Based Healthcare, 9, 3-24. doi: 10.1111/j.1744-1609.2010.00196.x

Goudarzian, A. H., Boyle, C., Beik, S., Jafari, A., Nesami, M. B., Taebi, M., \& Zamani, F. (2019). Self-care in Iranian cancer patients: The role of religious coping. Journal of Religion and Health, 58(1), 259-270. doi: 10.1007/s10943-018-0647-6

Hair, J. F., Black, W. C., Babin, B. J., Anderson, R. E., \& Tatham, R. L. (2009). Análise multivariada de dados [Multivariate analysis of data] ( $6^{\text {th }}$ Ed.). Porto Alegre, Brazil: Bookman.

Harrison, R. L., \& Westwood, M. J. (2009). Preventing vicarious traumatization of mental health therapists: Identifying protective practices. Psychotherapy: Theory, Research, Practice, Training, 46(2), 203-219. doi:10.1037/a0016081

Hau, K. T., \& Marsh, H. W. (2004). The use of item parcels in structural equation modelling: Non-normal data and small sample sizes. British Journal of Mathematical and Statistical Psychology, 57(2), 327-351. doi:10.1111/j.2044-8317.2004.tb00142.x 
Heidari, S., Rezaei, M., Sajadi, M., Ajorpaz, N. M., \& Koenig, H. G. (2017). Religious practices and self-care in Iranian patients with type 2 diabetes. Journal of Religion and Health, 56(2), 683-696. doi: 10.1007/s10943-016-0320-x

Henseler, J., Ringle, C. M., \& Sinkovics, R. R. (2009). The use of partial least squares path modeling in international marketing. In R. R. Sinkovics, \& P. N. Ghauri (Eds.), Advances in international marketing (pp. 277-319). Bingley: Emerald. doi: 10.1108/S14747979(2009)0000020014

Hernández, M. R. (2016). Autocuidado y promoción de la salud en el ámbito laboral [Selfcare and health promotion in the workplace]. Revista Salud Bosque, 5(2), 79-88. doi: $10.18270 /$ rsb.v5i2.1468

Jiang, X., Topps, A. K., \& Suzuki, R. (2020). A systematic review of self-care measures for professionals and trainees. Training and Education in Professional Psychology. Advance online publication. doi: 10.1037/tep0000318

Jim, H. S. L., Pustejovsky, J. E., Park, C. L., Danhauer, S. C., Sherman, A. C., Fitchett, G., Merluzzi, T. V. Munoz, A. R., Georg, L., Snyder, M., \& Salsman, J. M. (2015). Religion, spirituality, and physical health in cancer patients: A meta-analysis. Cancer, 121(21), 3760-3768. doi: 10.1002/cncr.29353

Jung, S. E., Kim, S., Bishop, A., \& Hermann, J. (2019). Poor nutritional status among lowincome older adults: Examining the interconnection between self-care capacity, food insecurity, and depression. Journal of the Academy of Nutrition and Dietetics, 119(10), 1687-1694. doi: 10.1016/j.jand.2018.04.009

Koenig, H. G. (2009). Research on religion, spirituality, and mental health: A review. The Canadian Journal of Psychiatry, 54(5), 283-291. doi: 10.1177/070674370905400502

Koenig, H. G. (2012). Religion, spirituality, and health: The research and clinical implications. ISRN Psychiatry, 1-33. doi: 10.5402/2012/278730

Koenig, H. G. (2015). Religion, spirituality, and health: A review and update. Advances in mind-body Medicine, 29(3), 19-26.

Koenig, H. G. (2018). Religion and mental health: research and clinical applications. Nueva York, NY: Academic.

Lee, J. J., Miller, S. E., \& Bride, B. E. (2020). Development and initial validation of the SelfCare Practices Scale. Social Work, 65(1), 21-28. doi: 10.1093/sw/swz045

Liu, C. J., Hsiung, P. C., Chang, K. J., Liu, Y. F., Wang, K. C., Hsiao, F. H., Ng S. M., \& Chan, C. L. (2008). A study on the efficacy of body-mind-spirit group therapy for patients with breast cancer. Journal of Clinical Nursing, 17(19), 2539-2549. doi: 10.1111/j.13652702.2008.02296.x

Lommi, M., Matarese, M., Alvaro, R., Piredda, M., \& De Marinis, M. G. (2015). L'evoluzione del concetto di cura di sé nell'assistenza sanitaria: Una revisione narrativa della letteratura [The evolution of the concept of self-care in the healthcare system: A narrative literature review]. Professioni Infermieristiche,68(2), 155-166. doi: 10.7429/pi.2015.682155

Lustyk, M. K. B., Widman, L., Paschane, A. A. E., \& Olson, K. C. (2004). Physical activity and quality of life: Assessing the influence of activity frequency, intensity, volume, and motive. Behavioral Medicine, 30, 124-131. doi: 10.3200/BMED.30.3.124-132

Magno, S. (2020). Self-care for health professionals. Recenti Progressi in Medicina, 111(4), 205-206. doi: 10.1701/3347.33182

Mandolesi, L., Polverino, A., Montuori, S., Foti, F., Ferraioli, G., Sorrentino, P., \& Sorrentino, G. (2018). Effects of physical exercise on cognitive functioning and wellbeing: Biological and psychological benefits. Frontiers in Psychology, 9, 1-11. doi: 10.3389/fpsyg.2018.00509 
Myers, S. B., Sweeney, A. C., Popick, V., Wesley, K., Bordfeld, A., \& Fingerhut, R. (2012). Selfcare practices and perceived stress levels among psychology graduate students. Training and Education in Professional Psychology, 6(1), 55-66. doi: 10.1037/a0026534

O'Boyle, E. H., \& Williams, L. J. (2011). Decomposing model fi t: Measurement vs. theory in organizational research using latent variables. Journal of Applied Psychology, 96(1), 112. doi: 10.1037/a0020539

Orem, D. E. (dir.) (2001). Nursing concepts of practice (6a ed.). St. Louis, MO: Mosby.

Park, C. L., \& Slattery, J. M. (2013). Religion, spirituality, and mental health. In R. F. Paloutzian, \& C. L. Park (Eds.), Handbook of the psychology of religion and spirituality (vol. 2; pp. 540 -559). Nueva York, NY: Guilford.

Parsian, N., \& Dunning, T. (2009). Developing and validating a questionnaire to measure spirituality: A psychometric process. Global Journal of Health Science, 1(1), 2-11. doi:10.5539/gjhs.v1n1p2

Pato, C., \& Corral, V. (2014, octubre 8-10). Conduta sustentável: Autocuidado, cuidado com os outros e com o planeta [Sustainable behavior: Self-care, caring for others and the planet] [comunicación oral]. I Congresso Brasileiro de Psicologia Positiva, Porto Alegre, Brasil.

Pituch, K. A., \& Stevens, J. P. (dirs.) (2016). Applied multivariate statistics for the social sciences: Analyses with SAS and IBM's SPSS (6a ed.). Nueva York, NY: Routledge.

Posluns, K., \& Lynn, T. (2020). Dear mental health practitioners, take care of yourselves: A literature review on self-care. International Journal for the Advancement of Counselling, 42(1), 1-20. doi: 10.1007/s10447-019-09382-w

Puchalski, C. M., Sbrana, A., Ferrell, B., Jafari, N., King, S., Balboni, T., Miccinesi, G., Vandenhoeck, A., Silbermann, M., Balducci, L., Yong, J., Antonuzzo, A., Falcone, A., \& Ripamonti, C. I. (2019). Interprofessional spiritual care in oncology: A literature review. ESMO Open, 4(1), 1-12. doi: 10.1136/esmoopen-2018-000465.

Rasmussen, H. N., Scheier, M. F., \& Greenhouse, J. B. (2009). Optimism and physical health: A meta-analytic review. Annals of Behavioral Medicine, 37(3), 239-256. doi: 10.1007/s12160-009-9111-x

Richard, A. A., \& Shea, K. (2011). Delineation of self-care and associated concepts. Journal of Nursing Scholarship, 43(3), 255-264. doi: 10.1111/j.1547-5069.2011.01404.x

Richards, K., Campenni, C., \& Muse-Burke, J. (2010). Self-care and well-being in mental health professionals: The mediating effects of self-awareness and mindfulness. Journal of Mental Health Counseling, 32(3), 247-264. doi: 10.17744/mehc.32.3.0n31v88304423806

Rodríguez-Muñoz, P. M., Carmona-Torres, J. M., \& Rodríguez-Borrego, M. A. (2020). Influence of tobacco, alcohol consumption, eating habits and physical activity in nursing students. Revista Latino-Americana de Enfermagem, 28, 2-9. doi: 10.1590/15188345.3198.3230

Rushton, C. H., Batcheller, J., Schroeder, K., \& Donohue, P. (2015). Burnout and resilience among nurses practicing in high-intensity settings. American Journal of Critical Care, 24(5), 412-421. doi: 10.4037/ajcc2015291

Salovey, P., Mayer, J. D., Goldman, S. L., Turvey, C., \& Palfai, T. P. (1995). Emotional attention, clarity, and repair: Exploring emotional intelligence using the Trait Meta-Mood Scale. In J. W. Pennebaker (Ed.), Emotion, disclosure, \& health (pp. 125-154). Washington, DC: American Psychological Association.

Sansó, N., Galiana, L., Oliver, A., Pascual, A., Sinclair, S., \& Benito, E. (2015). Palliative care professionals' inner life: Exploring the relationships among awareness, self-care, and compassion satisfaction and fatigue, burnout, and coping with death. Journal of Pain and Symptom Management, 50(2), 200-207. doi: 10.1016/j.jpainsymman.2015.02.013 
Santana, M. C., \& Fouad, N. A. (2017). Development and validation of a Self-Care Behavior Inventory. Training and Education in Professional Psychology, 11(3), 140-145. doi: 10.1037/tep0000142

Sharif Nia, H., Pahlevan Sharif, S., Goudarzian, A. H., Allen, K. A., Jamali, S., \& Heydari Gorji, M. A. (2017). The relationship between religious coping and self-care behaviors in Iranian medical students. Journal of Religion and Health, 56(6), 2109-2117. doi: 10.1007/s10943-017-0376-2

Shrivastava, S. R., Shrivastava, P. S., \& Ramasamy, J. (2013). Role of self-care in management of diabetes mellitus. Journal of diabetes y Metabolic Disorders, 12(1), 14, 2-5. doi: 10.1186/2251-6581-12-14

Steinhorn, D. M., Din, J., \& Johnson, A. (2017). Healing, spirituality, and integrative medicine. Annal Palliative Medicine, 6, 237-247. doi: 10.21037/apm.2017.05.01

Unadkat, S., \& Farquhar, M. (2020). Doctors' wellbeing: self-care during the covid-19 pandemic. British Medical Journal, 368, 1-2. doi: 10.1136/bmj.m1150

Valiente-Barroso, C., Sáiz-Obeso, J., \& Martínez-Vicente, M. (2021). Satisfacción vital y sintomatología prefrontal como predictores de la atención plena disposicional en la mujer rural[Vital satisfaction and prefrontal symptoms as predictors of dispositional mindfulness in rural women]. Behavioral Psychology/Psicología Conductual, 29(2), 489503. doi: https://doi.org/10.51668/bp.8321215s

Vidal-Blanco, G., Oliver, A., Galiana, L., \& Sansó, N. (2019). Quality of work life and self-care in nursing staff with high emotional demand. Enfermería Clínica, 29(3), 186-194. doi: 10.1016/j.enfcle.2018.10.001

Walker, R. J., Gebregziabher, M., Martin-Harris, B., \& Egede, L. E. (2014). Independent effects of socioeconomic and psychological social determinants of health on self-care and outcomes in Type 2 diabetes. General Hospital Psychiatry, 36(6), 662-668. doi: 10.1016/j.genhosppsych.2014.06.011

White, M. L. (2016). Spirituality self-care practices as a mediator between quality of life and depression. Religions, 7(5), 54, 1-10. doi: 10.3390/rel7050054

White, M. L., \& Myers, S. (2013). Development of a spiritual self-care practice scale. Journal of Nursing Measurement, 21(3), 450-462. doi: 10.1891/1061-3749.21.3.450

White, M. L., Peters, R., \& Schim, S. M. (2011). Spirituality and spiritual self-care. Nursing Science Quarterly, 24(1), 48-56. doi: 10.1177/0894318410389059

Yee, L. M., McGuire, J. M., Taylor, S. M., Niznik, C. M., \& Simon, M. A. (2015). Factors promoting diabetes self-care among low-income, minority pregnant women. Journal of Perinatology, 36(1), 13-18. doi: 10.1038/jp.2015.134

ReCEIVED: August 22, 2020

ACCEPTED: April 3, 2021 


\section{Appendix}

\section{The Self-Care Behavior Scale \\ (Torres, Corral, \& Corral, 2021)}

Select the answer with which you most feel identified by crossing out with an " $X$ ". We remind you that there are no correct or incorrect answers, only declare your opinion of the statements presented below.

\begin{tabular}{|c|c|c|c|c|c|}
\hline Ítems & Never & \begin{tabular}{|c} 
Almost \\
never
\end{tabular} & $\begin{array}{l}\text { Occasi } \\
\text { onally }\end{array}$ & $\begin{array}{l}\text { Almost } \\
\text { always }\end{array}$ & Always \\
\hline 1. I do some kind of physical activity. & & & & & \\
\hline 2. I try to eat healthy foods. & & & & & \\
\hline $\begin{array}{l}\text { 3. I use to alternate the position of my body } \\
\text { throughout the day to preserve my health. }\end{array}$ & & & & & \\
\hline $\begin{array}{l}\text { 4. I frequently examine my body to see if there } \\
\text { are any changes. }\end{array}$ & & & & & \\
\hline 5. I moderate the use of salt in my diet. & & & & & \\
\hline 6. I get enough sleep to feel rested. & & & & & \\
\hline $\begin{array}{l}\text { 7. I make changes in my eating habits to keep } \\
\text { control of my weight }\end{array}$ & & & & & \\
\hline $\begin{array}{l}\text { 8. I make changes to my bad habits to maintain } \\
\text { my health. }\end{array}$ & & & & & \\
\hline $\begin{array}{l}\text { 9. I attend periodic medical check-ups to } \\
\text { maintain my health. }\end{array}$ & & & & & \\
\hline $\begin{array}{l}\text { 10. Before taking a medicine, I get all the } \\
\text { information about the harmful effects on my } \\
\text { health. }\end{array}$ & & & & & \\
\hline $\begin{array}{l}\text { 11. I try not to self-medicate when I have pain or } \\
\text { illness. }\end{array}$ & & & & & \\
\hline $\begin{array}{l}\text { 12. I make changes in my habits to maintain my } \\
\text { weight. }\end{array}$ & & & & & \\
\hline $\begin{array}{l}\text { 13. I maintain personal hygiene practices every } \\
\text { day (dental hygiene, hand washing, bathing, } \\
\text { cutting nails, etc.). }\end{array}$ & & & & & \\
\hline 14. I try to brush my teeth three times a day. & & & & & \\
\hline 15. I try to bathe daily. & & & & & \\
\hline 16. I keep my nails short and clean. & & & & & \\
\hline 17. I rest to regain my health and energy. & & & & & \\
\hline $\begin{array}{l}\text { 18. I consume at least three meals a day } \\
\text { (breakfast, lunch and dinner). }\end{array}$ & & & & & \\
\hline 19. I eat a balanced diet to maintain my health. & & & & & \\
\hline $\begin{array}{l}\text { 20. I avoid consuming foods that harm my health } \\
\text { (fats, salts, sausages, sweets, soda, etc.). }\end{array}$ & & & & & \\
\hline 21. I usually worry a lot about how I feel. & & & & & \\
\hline $\begin{array}{l}\text { 22. I usually spend time thinking about my } \\
\text { emotions. }\end{array}$ & & & & & \\
\hline 23. I often think about my feelings. & & & & & \\
\hline $\begin{array}{l}\text { 24. I think my emotions and mood are worth } \\
\text { paying attention to. }\end{array}$ & & & & & \\
\hline
\end{tabular}




\begin{tabular}{|c|c|c|c|c|c|}
\hline Ítems & Never & $\begin{array}{c}\text { Almost } \\
\text { never }\end{array}$ & $\begin{array}{l}\text { Occasi } \\
\text { onally }\end{array}$ & $\begin{array}{l}\text { Almost } \\
\text { always }\end{array}$ & Always \\
\hline 25. I try to be in a good mood. & & & & & \\
\hline $\begin{array}{l}\text { 26. When I am sad, I think of all the pleasures in } \\
\text { life. }\end{array}$ & & & & & \\
\hline $\begin{array}{l}\text { 27. Although sometimes I feel sad, I usually have } \\
\text { an optimistic vision. }\end{array}$ & & & & & \\
\hline $\begin{array}{l}\text { 28. I do activities to rest from daily worries (read } \\
\text { a book, do sports, go for a run, among } \\
\text { others). }\end{array}$ & & & & & \\
\hline 29. I take the time to do things that I like. & & & & & \\
\hline $\begin{array}{l}\text { 30. I try to maintain a balance between my body, } \\
\text { my emotions and my mind. }\end{array}$ & & & & & \\
\hline $\begin{array}{l}\text { 31. I participate in activities that help me to be a } \\
\text { better person. }\end{array}$ & & & & & \\
\hline 32. I do activities that generate well-being. & & & & & \\
\hline 33. I try to get to know myself better every day. & & & & & \\
\hline 34. I do things that give me pleasure. & & & & & \\
\hline $\begin{array}{l}\text { 35. I enjoy maintaining healthy relationships with } \\
\text { others. }\end{array}$ & & & & & \\
\hline 36. Every day I try to be at peace with myself. & & & & & \\
\hline $\begin{array}{l}\text { 37. After work (or study) I try to reward myself } \\
\text { with any pleasant activity. }\end{array}$ & & & & & \\
\hline $\begin{array}{l}\text { 38. When I perceive that I am stressed, I try to } \\
\text { think of other things. }\end{array}$ & & & & & \\
\hline $\begin{array}{l}\text { 39. Even if I feel bad, I try to think of pleasant } \\
\text { things. }\end{array}$ & & & & & \\
\hline $\begin{array}{l}\text { 40. I try to think positive thoughts, even if I feel } \\
\text { bad. }\end{array}$ & & & & & \\
\hline $\begin{array}{l}\text { 41. I am aware of my feelings in different } \\
\text { situations. }\end{array}$ & & & & & \\
\hline 42. I know well how I feel. & & & & & \\
\hline $\begin{array}{l}\text { 43. To keep my mind relaxed and calm, I do } \\
\text { activities that help me feel better. }\end{array}$ & & & & & \\
\hline 44. I experience satisfaction after meditating. & & & & & \\
\hline $\begin{array}{l}\text { 45. I turn to meditation to find inner peace and } \\
\text { strength. }\end{array}$ & & & & & \\
\hline $\begin{array}{l}\text { 46. I practice spiritual activities to find harmony } \\
\text { with the world. }\end{array}$ & & & & & \\
\hline $\begin{array}{l}\text { 47. I feel connected to a being greater than } \\
\text { myself (God). }\end{array}$ & & & & & \\
\hline $\begin{array}{l}\text { 48. I practice spiritual practices to maintain my } \\
\text { health (yoga, tai chi, meditation, praying, } \\
\text { biblical coexistence groups, reading spiritual } \\
\text { texts, etc). }\end{array}$ & & & & & \\
\hline $\begin{array}{l}\text { 49. My relationship with a higher being (God) } \\
\text { helps me to love others. }\end{array}$ & & & & & \\
\hline 50. I have learned to forgive other people. & & & & & \\
\hline 51. I have learned to forgive myself. & & & & & \\
\hline
\end{tabular}




\begin{tabular}{|l|l|l|l|l|l|}
\hline \multicolumn{1}{|c|}{ Ítems } & Never & $\begin{array}{c}\text { Almost } \\
\text { never }\end{array}$ & $\begin{array}{c}\text { Occasi } \\
\text { onally }\end{array}$ & $\begin{array}{c}\text { Almost } \\
\text { always }\end{array}$ & Always \\
\hline $\begin{array}{l}52 . \text { I seek comfort through spiritual means } \\
\text { (prayer, meditation, attending religious or } \\
\text { spiritual services, or taking spiritual } \\
\text { counseling). }\end{array}$ & & & & & \\
\hline
\end{tabular}

